\title{
Western European Prototypes in the Cult Architecture of the Lower Volga Region (Second Half of the XVIII - Early XX Centuries)
}

\author{
Valentina Serebryanaya ${ }^{1, *}$ Olga Kozlova ${ }^{2, a}$ Yury Kolyshev ${ }^{1, b}$
}

\author{
${ }^{1}$ Department of Urban Design, Institute of Architecture and Civil Engineering, Volgograd State Technical University, \\ Volgograd, Russia \\ ${ }^{2}$ Department of Linguistics and Intercultural Communication, Institute of Architecture and Civil Engineering, Volgograd \\ State Technical University, Volgograd, Russia \\ aE-mail: kornienko_o@list.ru \\ bE-mail: tango7412@gmail.com \\ *Corresponding author. E-mail: val38@mail.ru
}

\begin{abstract}
The article considers both preserved and lost Roman Catholic and Evangelical Lutheran churches located in the territory of the multi-ethnic and multi-confessional region of the Lower Volga region. The presence of national cultures of Poles, Germans determined the distinctive features of the development of religious construction, especially in places of compact residence. The basis for the emergence and development of the churches of Lutherans, Catholics, Mennonites, was the traditional Western European architecture. Roman Catholic and Evangelical Lutheran churches are an integral part of the cultural heritage of the Lower Volga, which has not yet been studied. The study of the sources, as well as the field survey, revealed the typology of the cult architecture of the colonists, and its planning, volumetric, spatial, constructive, and stylistic solutions. The characteristic features of the organization and construction of the Roman Catholic and Evangelical Lutheran churches of the colonial settlements of the Lower Volga region associated with Western European traditions are revealed.
\end{abstract}

Keywords: West Christian churches, colonial architecture, Volgograd region

\section{INTRODUCTION}

In the Volgograd region, monuments of religious architecture of foreign immigrants (mainly Germans) have high historical and cultural value. German colonies formed the core of the Western Christian population of the Saratov province. The churches built by the settlers were the best manifestation of the traditions of European West Christian church architecture. Many Roman Catholic and Evangelical Lutheran churches have been destroyed during the Soviet period. The surviving ones were used for other functions, which led to the loss of the initial layout and appearance. Since the 1990s, the formation of confessional communities and religious associations has revived, and the construction of new West Christian churches has started again. In this regard, the relevance of this study lies in the need for a comprehensive analysis of the architecture of the Roman Catholic and Evangelical Lutheran churches of the Lower Volga region (primarily on the example of the Volgograd region).
The purpose of the research is to determine the impact of traditional Western European cult architecture on the construction of religious buildings in the Lower Volga region.

The objectives of the research are the study of the preserved objects of Western Christian churches in the Lower Volga region, the identification of their typological and stylistic features, field surveys, and photo fixations of the survived monuments.

The research methodology is based on a comprehensive comparative historical analysis of planning, volumetric, spatial, and stylistic decisions of the architecture of Western Christian churches of the mid-XVIII - early XX centuries. In order to recreate a more complete picture of religious construction in the region, lost objects are used.

The acquaintance with the scientific development of a topic devoted to a comparative analysis of traditional Western European cult architecture and colonial architecture in the Lower Volga region indicates the absence of specialized works. In Russian 
historiography, preference was given to studying the construction of Orthodox churches.

The valuable sources for research were the works of pre-revolutionary authors from the German colonies of the Saratov province [1]. The most notable contemporary researcher of the architectural and urban planning heritage of Russian Volga Germans is S.O. Teryokhin. He has published numerous works both in Russia and abroad. The most significant work is the monograph "German Settlements in Russia. An architectural phenomenon" [2].

An important place among the sources used is taken by archival materials. The most complete information on churches is contained in the GASO materials of the Russian State Historical Archive, which have been also used.

The scientific novelty of this study lies in the fact that sacral objects of the mid XVIII - early XX centuries in the colonies of the Lower Volga region are, for the first time, comprehensively considered in the categories of time, image, style, and tradition. Field and archival materials are summarized. A comparative analysis of the cult Western European architecture with the West Christian heritage of the region has led to the conclusion that the main types of churches of immigrants have incorporated the architectural features of their former places of residence.

\section{REVIEW}

Due to historical circumstances, the Volgograd region is a large part of the territory of the former Saratov province and the Don Army, unusually diverse in its ethnic composition. The presence of various national cultures left its mark on the formation of the cult architecture of this area. This is due to the intensive colonization of the steppe expanses of the South of Russia, the banks of the Volga, and the Don. Since ancient times, a long process of economic and cultural development of these lands has been going there.

Particularly active settlement of lands in the South of Russia by foreign settlers begins in the middle of the XVIII century under Catherine II. She issued manifestos in 1762 and in 1763, which spoke about the conditions and rights of immigrants from Europe. By decree of March 19, 1764, places for settlement have been determined. The settlers were mostly Germans. They arrived in the Saratov province from different parts of Germany and primarily in the Kamyshin and Tsaritsyn districts and have created 190 colonies.

An important place in the settlements was given to churches. The Germans have brought the essential branches of Christianity to the Volga region, as they were mostly Lutherans, Catholics, and Mennonites. By 1804, 115 churches (59 Lutheran, 33 Catholic) have been built in the Saratov province. Intensive cult construction in the German colonies of the Volga region unfolded in the XIX century. So, by 1888 there have been 83 Lutheran churches and 38 Catholic ones. The construction was carried out in various stylistic directions.

Both German and Russian architects worked on church projects. Among them were the architects of the Saratov and Samara provinces: B. Neumann, K. Dientzenhofer, J. E. Jacobsthal, F. Lagus, K. Gihien, P. Hess, A. Klementyev, Yu. Terlikov.

Of particular value to the Western Christian architectural and urban heritage in the Lower Volga region is the first colony on the Old Sarepta, 28 miles from Tsaritsyn (the southern part of the city of Volgograd). It was often referred to as the "one of the most delightful corners of the Volga region". There, on September 14, 1765, the first envoys of the Fraternal Union from Hernnhut have arrived. As a result of three waves of immigration of the Germans-hernnhutters, 200 people have been living in Sarepta by 1769. The stone church in Sarepta is the earliest monument of immigrants from Germany in the Volga region. It was founded in May 1771 and consecrated on September 3, 1772. Its architecture reflected the simple ascetic lifestyle of the Hernnhutters. A Kirche (germ. church) is a small stone building with a chamber character. Its architecture is simple and concise. The construction of the plan is typical for the type of hall church. The master combined in this building the features of civil and cult medieval architecture (the town hall with a pointed roof and a bell tower with a spire in the center of the church ridge). ("Fig. 1") 


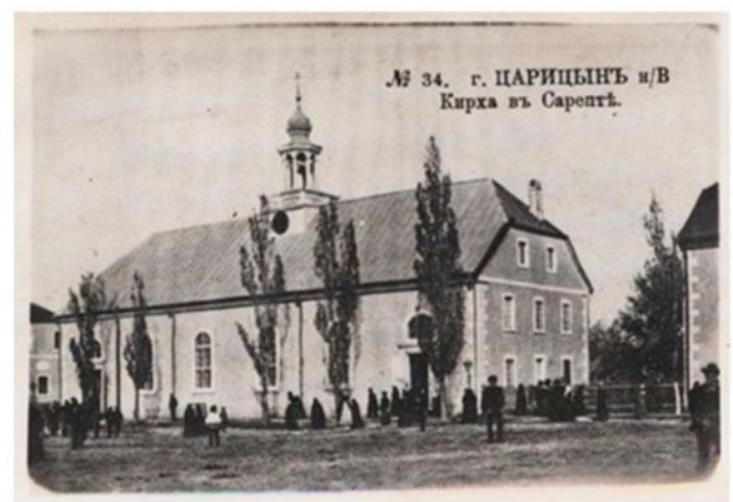

a

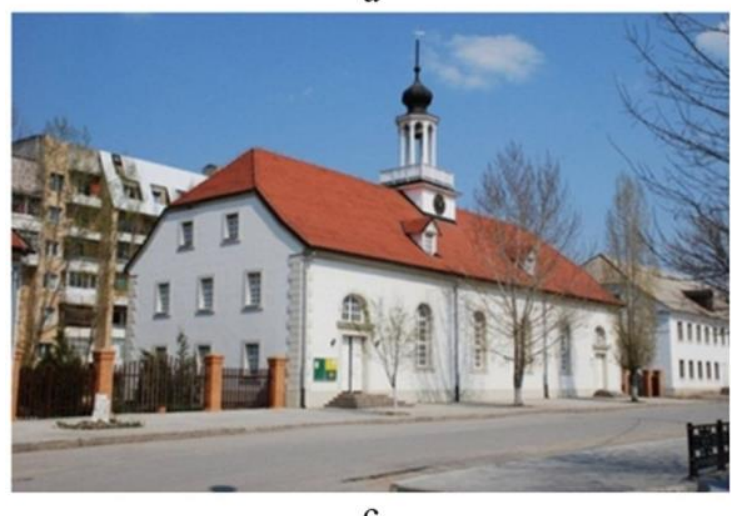

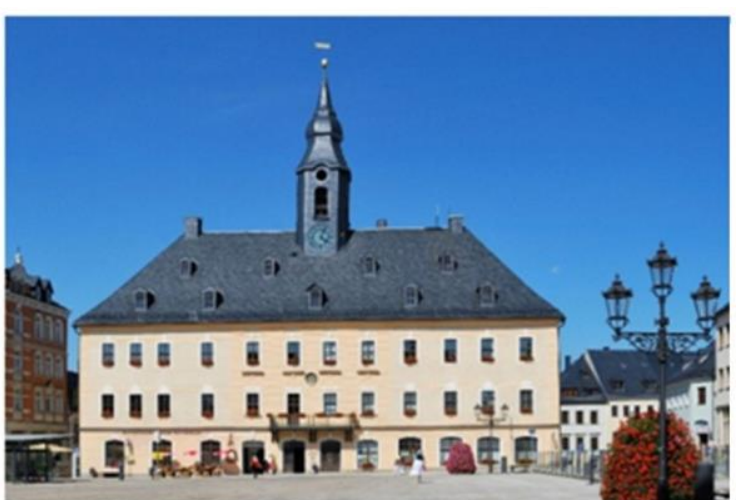

b

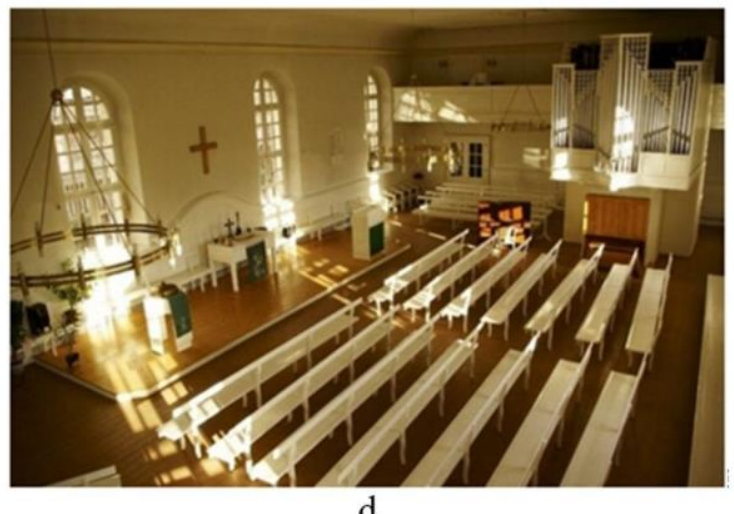

d

Fig. 1. a, c, d-the Church in Sarepta, b - Town Hall (Annaberg, Germany).

\section{TYPES AND STYLES OF WEST CHRISTIAN CHURCHES}

In the German colonies of the Volga region, intensive cult construction unfolded in the XIX century. In a number of churches of the XIX century, Volga Germans embodied aesthetic ideals and architectural and artistic forms of Gothic Cathedrals.

Lutheran churches. In the Lower Volga region, the construction of Lutheran churches prevailed. The first Lutherans (Protestants) appeared in the Saratov province in 1767. Alongside with the immigrants of other faiths who came at the invitation of Catherine II, they have formed three colonies. From 1768 to 1771, seven more Lutheran congregations have appeared. In 1785, a Lutheran town consistory was opened in Saratov. By this time in the Saratov colonies, there have been 9 Lutheran church parishes and 3 Reformed ones. In addition, there was a Lutheran community in Saratov. Thus, by the beginning of the XIX century, the number of parishes in the Saratov Volga has increased to 16 . In 1885 there have already been 120 of them in the Volga region. Architects drew inspiration for their buildings from medieval models. The examples of Lutheran churches in the Volgograd and Saratov regions and their comparison with Western counterparts given in the article allow us to compose a presentation on the main typological and stylistic changes.

The first stone Evangelical Lutheran Church of St. Mary was built in 1879 on to the project of the Saratov architect of German origin K.V. Tiden. Its architecture was borrowed from the European Gothic style. It is close to the first Lutheran church in the city of Jelgava in Latvia (the former town of Mitau, the Province of Courland). Tiden was well acquainted with the architecture of Courland, since at the end of the building school, he was sent to the Baltic states, to the Courland province, to the construction and road commission, in 1857 he was transferred to Saratov. Perhaps, the project by Tiden K.V.was used for the construction of the Lutheran church in Zorkino (Zürich) and Susly Herzog in 1877. ("Fig. 2") 


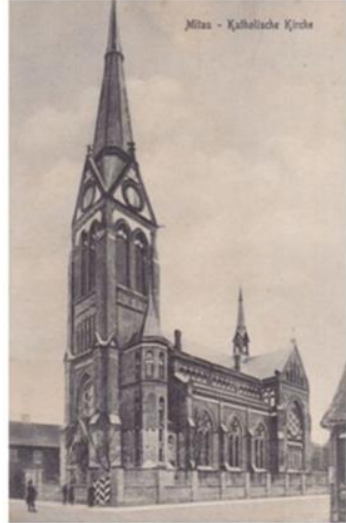

a

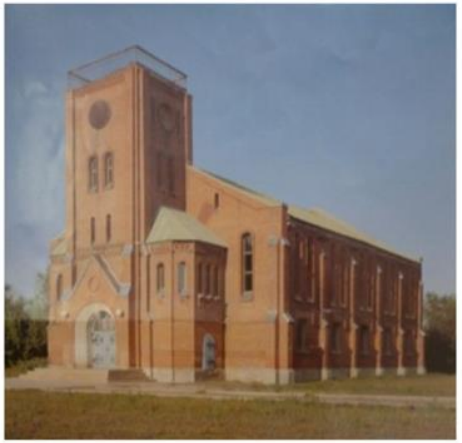

d

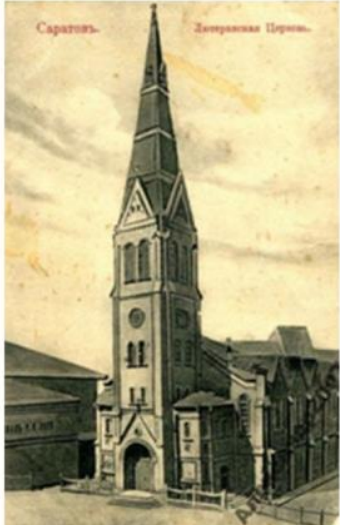

b

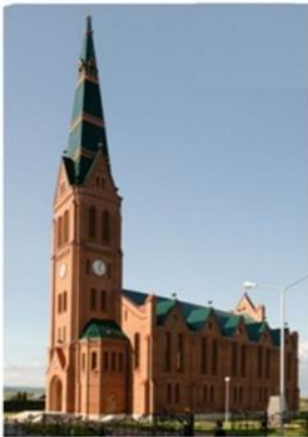

e

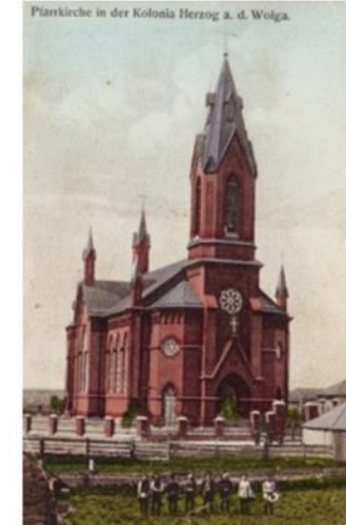

c

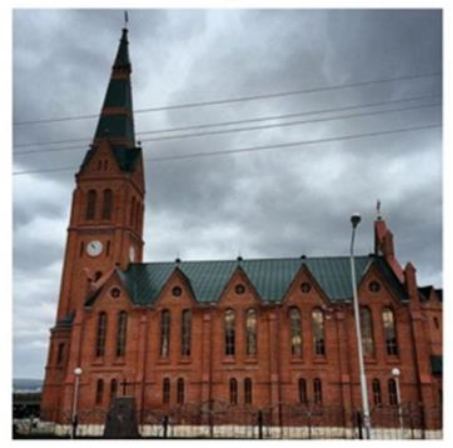

f

Fig. 2. $\mathrm{a}-$ Mitau, $\mathrm{b}-$ Saratov, $\mathrm{c}-$ Susly (Herzog), d-f - Zorkino (Zürich).

The Church of St. Mary in Saratov became a model for the Protestant church in Tsaritsyno. By the way, initially, the Protestants of Tsaritsyn were served by hernnhutters from Sarepta. Only in 1894, an independent parish has been formed here. The Lutheran Church was built in Astrakhan, following the example of the Church in Saratov.

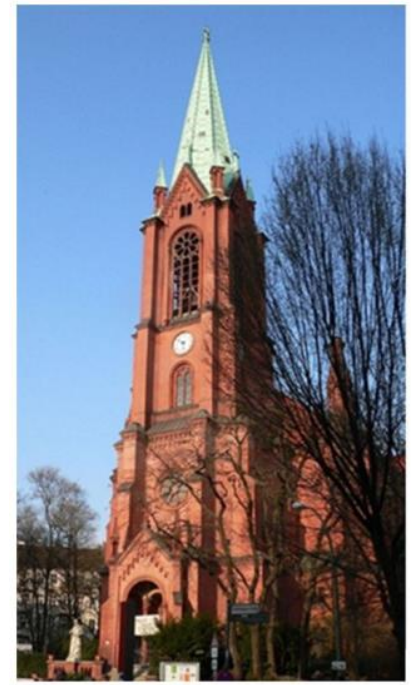

a

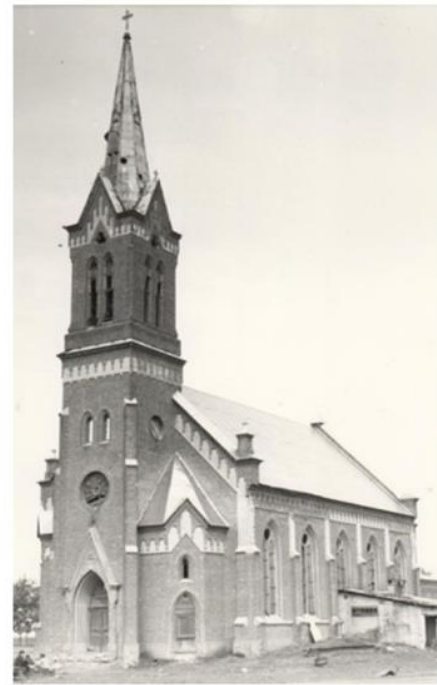

b
An appeal to Western traditions in the architectural design of churches in the villages of Verkhny Yeruslan (1884-1886) and Grechikhino (1900) in the Volgograd Region is obvious. [3] The church in Grechikhino was designed by local craftsmen Jacob Maar and Jacob Shesler. ("Fig. 3")
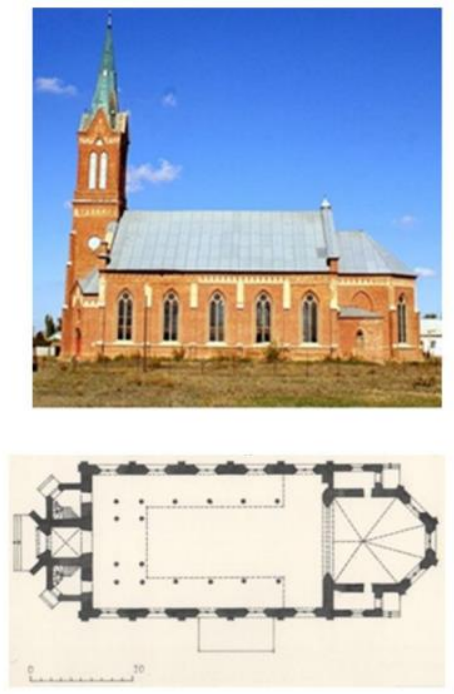

c

Fig. 3. a-Emmauskirche (Berlin), b, c-Verkhny Yeruslan. 
Both churches are built of brick and have almost identical volumetric composition. These are large buildings with an abundant silhouette comprised of towers. Although the architecture of the towers is somewhat different. The church tower in Verkhny Yeruslan on a square base, crowned by a steep spire, is slenderer. The forms of these churches are close to Gothic patterns (lancet terminations of a promising portal, elongated lancet windows, high spire-shaped completion). The churches have an elongated composition, stretched along the west-east axis, which consists of three organically connected parts: a high tower, a rectangular in plan room, a strongly protruding five-sided apse. In the decoration of the façades, polychrome is used. Bindings of roses play an important role in the decor of the churches; tall elongated windows of the Gothic pattern hide the massiveness of the walls and give them elegance, harmony, and lightness. The interiors are designed as hall churches. They freely open up and down. The volume of apses flows into the central space, which receives abundant illumination from huge windows. Of the two churches under consideration, the most interesting is the interior of the frame in Verkhny Yeruslan. Many elements of decoration have survived there: empirics located in the church from three sides, matronea wooden poles with ionic capitals, decorative modulons, and arcature on a wooden parapet. A beautiful floral pattern on the steps and rails of cast-iron stairs are located in the narthex and passages to matronea.

The architecture of the Yeruslan and Grechikhino churches point to an evident appeal to the traditions of the German hall-type Gothic churches, such as St. Martin's Church (1389-1507) - an exemplar of a Bavarian brick Gothic hall church and the Protestant Emmauskirche in Berlin, built in the 1890s in the NeoGothic style. The Yeruslan and Grechikhino churches differ from their prototypes due to the simplification of their external as well as the interior forms. Large ecclesiastical buildings sprung up everywhere in the Saratov province, freely copying Western European architecture of the Neo-Gothic style. One such example is the Lutheran church in the village of Lipovka (Schäfer, 1906). The Church of St. Anthony in UstZolikha (Messer, 1912) is the most significant from the architectural perspective. It is a massive edifice in the Neo-Roman style with Neo-Gothic elements. It is distinguished by its well-designed composition, the high quality of craftsmanship, and a superior decorative façade. The eclectic Romanticism of the late XIX early XX centuries is clearly recognizable in its design. The church in Ust-Zolikha reminiscents of the Zionskirche in Berlin (1866-1873). ("Fig. 4")
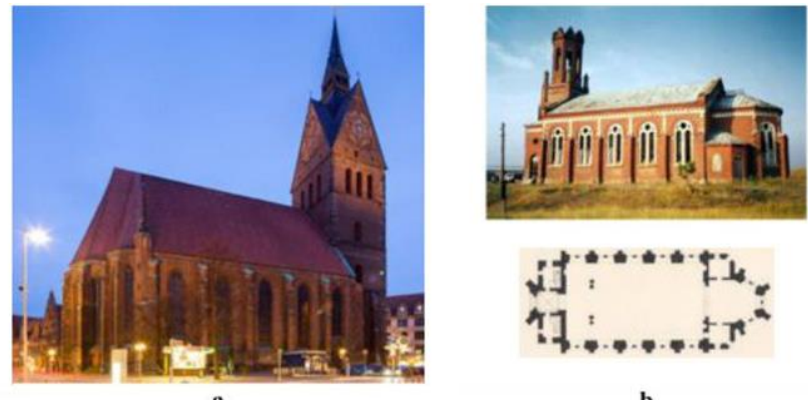

b
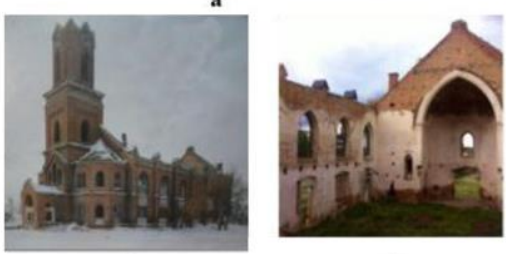

d
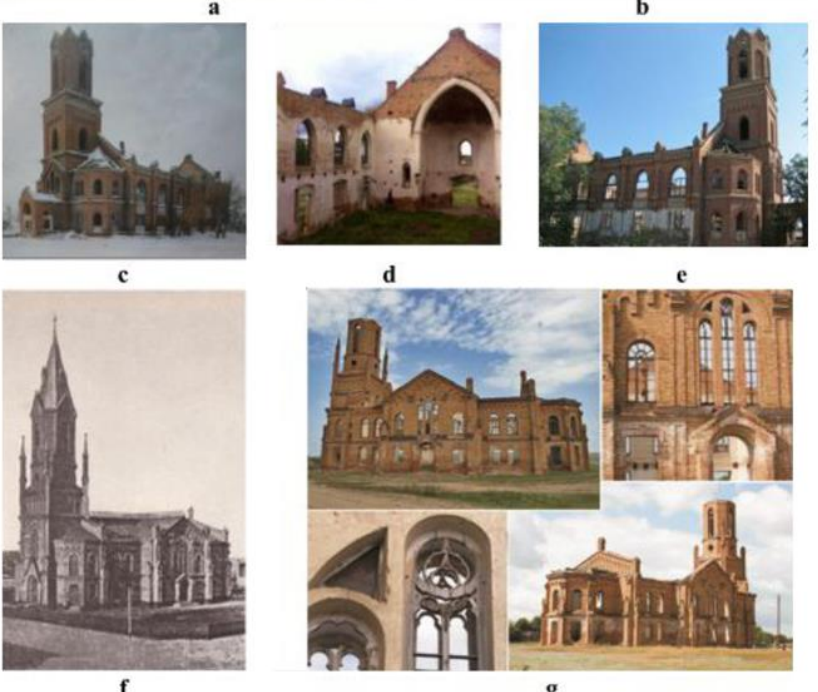

g

Fig. 4. $\mathrm{a}-$ Zionskirche (Berlin), $\mathrm{b}-$ Grechikhino, $\mathrm{c}-\mathrm{g}-$ Ust-Zolikha. 
Of equal interest are churches of Western Christian denominations designed by architects who drew inspiration from the traditions of both European and Russian Classicism. Erected during the late Classicism, these buildings stood in opposition to the Neo-Gothic tradition. Church projects that departed from the forms of traditional architecture were restricted by the regulations imposed by building legislation. The Lutheran church in the village of Nizhnyaya Dobrinka (Moninger, 1845), shares many features with the compositions of late Classicism. An analysis of its architectural features suggests that the architect, who,

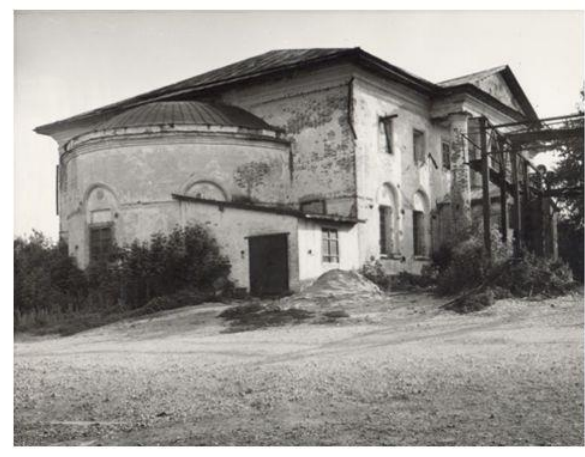

a

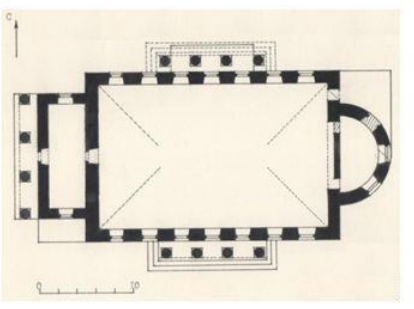

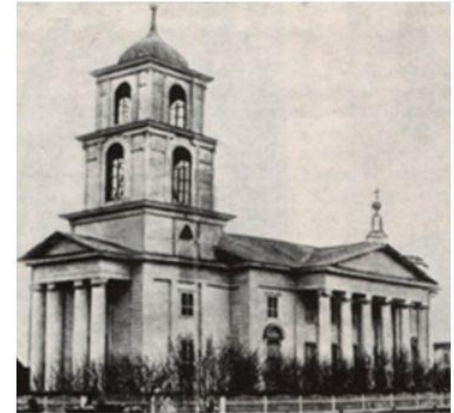

d although followed the traditions of Russian Classicism, did not ignore the traditions of German architecture. While it undoubtedly has a classical composition, the church also includes Gothic elements in its interior design. It is a hall-type church. Its composition consists of a two-lined rectangular in terms of volume, fourcolumned Tuscan porticoes, ending with classic triangular gables, and a large apse. The decor is humble and concise. The discovered architectural drawings of a church in the Schaffhausen colony (Volkovo, 1833) indicate that the composition of the two churches is the same in volume, and their plans correspond. ("Fig. 5")

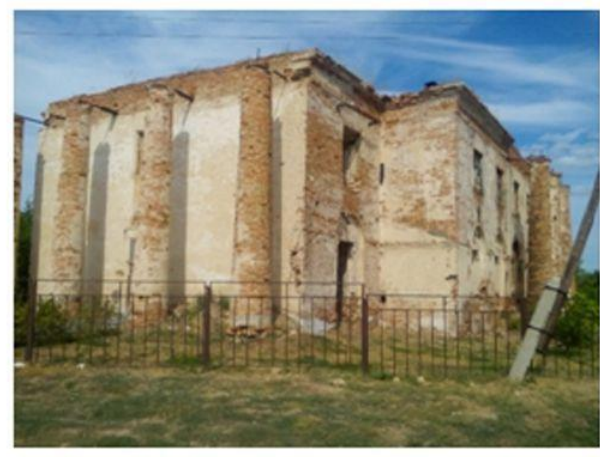

b

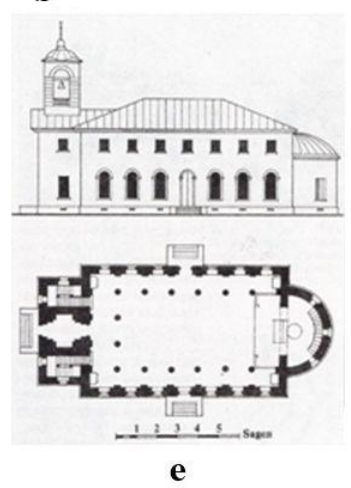

Fig. 5. a, b, c-Nizhnyaya Dobrinka. (a - 1990, b-2019.) d-Graf, e-Schaffhausen.

Catholic Cathedrals. Catholics were the secondlargest denomination among the settlers in the Lower Volga region and were predominantly of German origin. They started to settle in Saratov province after the decree by Catherine II in 1763. The Cathedrals of the Catholic colonies known to us display tendencies towards traditional heritage in their architectural design. Over time, the initial houses of prayer have been replaced by permanent stone churches. The Catholic stone churches could be distinguished from the more austere Lutheran ones by their flexibility and façades decorativeness. The biggest differences could be seen in the interior design of the buildings (stain glass, sculptures, podiums, and tabernacles). Catholic churches were also built in the Neo-Gothic style. One example is the Cathedral in the village of Susla (Herzog, 1906), designed by architect, G. König. König preferred the Gothic Style. The church in Kamenka ( 1907) was also based on König's design.

Catholic churches in the Lower Volga region have been built not only by settlers from Germany. Catholicism in the Lower Volga region was spread from the end of the XVI century predominantly among foreign merchants who settled in certain Russian cities. In the Lower Volga region, Astrakhan, through which it was possible to trade with the East, was one such city. In 1606-1607, Carmelite monks sent as missionaries by the Pope traveled along the Volga and visited Tsaritsyn and Astrakhan [4]. The Catholic mission was established in Astrakhan. There are no records of the construction of the first Roman Catholic Cathedral in Astrakhan. However, it is known that the existing church stands on the site of the former stone church building, built by Capuchin monks in 1721. The New 
Uspenskyi Cathedral (1762-1778), was dedicated by the permission of Pope Pius VI. Its design shows the characteristic features of European Cathedrals of the second half of the XVII and the first half of the XVIII centuries. The spacious composition with two symmetrical bell towers of the main façade of the Astrakhan church was influenced by similar structures that were widespread not only in Southern Europe but could also be seen among the Northern European baroque churches. The Astrakhan Cathedral is at its core a type of domed basilica. This type of structure was introduced into the cult architecture of the region by the monastic orders. The decoration of the main façade is typical of the late Baroque period with some elements of Classicism. The interior is expressive.

Polish Catholics also lived in the Lower Volga region, mainly in the Saratov Volga Region. The influx of Polish immigrants intensified after the events in Poland of 1830-1831. In 1847, the Catholic parishes of southern Russia entered the Kherson diocese. The Saratov province became part of the diocese. The seat of the diocese later moved to Tiraspol, and in 1856 Saratov became its center, which prompted the construction of a stone Cathedral (1873-1880) designed by M.N. Grudistov [5]. The Cathedral was built in the Roman Gothic tradition modeled on Northern European Cathedrals. The composition included two bell towers with Apostle Peter standing between them, which reinforced the imposing character of the building. In the 1930s, the Cathedral was closed and rebuilt.

The Tsaritsyn (Volgograd) parish was part of the Saratov diocese. In 1898, 430 Poles lived in Tsaritsyn. A Cathedral was built in 1899. The technicalconstruction committee of the Ministry of Internal Affairs applied for permission to build the Cathedral, enclosing the design drawings. The design was rejected and replaced with the design drawings for the Cathedral in Plock [6]. The façade structure of the Tsaritsyn Cathedral is close to that of the Cathedral of St. Bartholomew in Plock (1730s) and is in the Baroque style. Although the architecture of the Tsaritsyn Cathedral closely resembles the Romanesque style, there are also elements of the Baroque style. The Cathedral is of the hall-type with its belfry on the main facade vertically articulated with buttresses. The decor is centered on the main facade. ("Fig. 6")
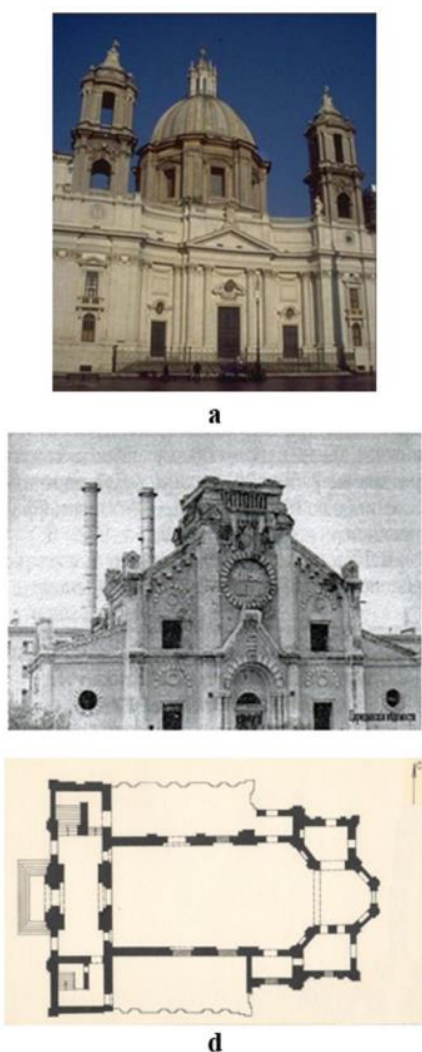

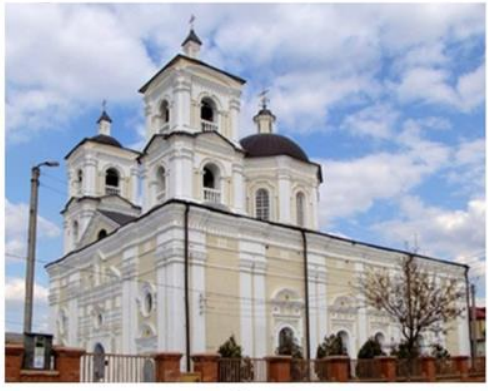

b

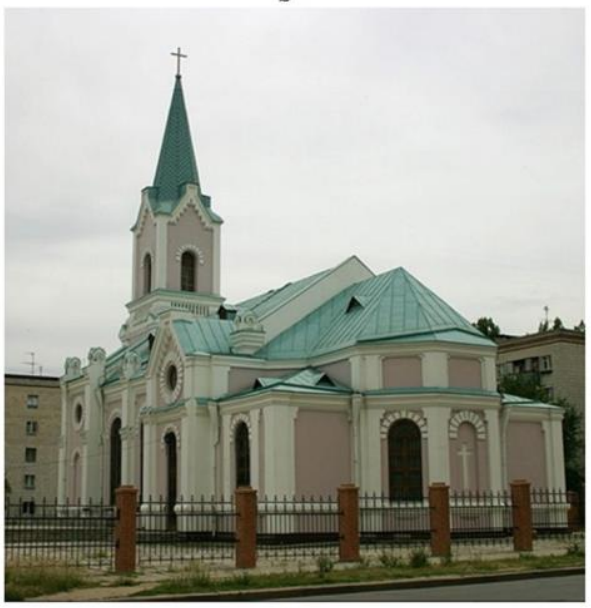

e
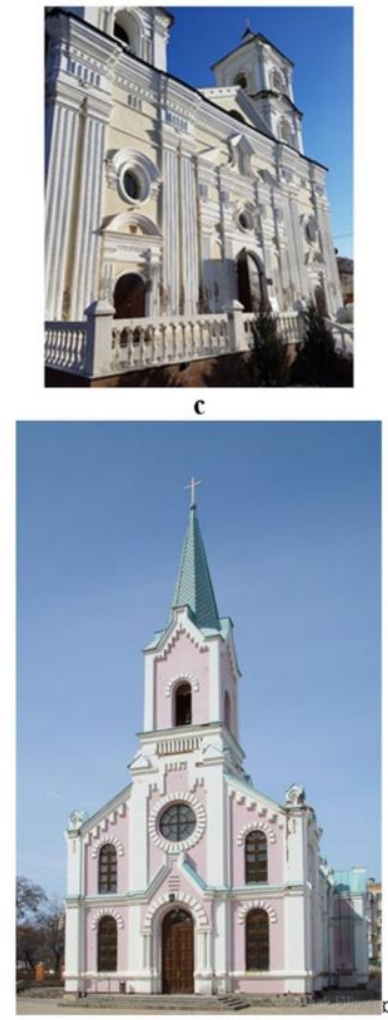

Fig. 6. a, b, c-Astrakhan, d, e, f - Tsaritsyn.

\section{CONCLUSION}

The study examined both existing and lost churches. It shows the development of the architecture of Western
Christian churches built by foreign settlers in the Lower Volga region. The study reveals that numerous churches built by the settlers fairly accurately reflect the traditions of the confessional architecture of the second 
half of the XVIII - the beginning of XX centuries. The primary group of both Roman Catholic and Evangelical Lutheran churches were built in the Neo-Gothic style and belong to the volumetric type of a hall church with a tower. During the Soviet period, these buildings suffered significant damage, with dozens of monuments still lying in ruins. It is highly important to preserve this rich heritage and perform urgent restoration works.

\section{References}

[1] A.A. Klaus, Our colonies: Experience and Materials on the History and Statistics of Foreign Colonization in Russia, 1st ed., St. Petersburg, 1869, p.7; Colony of Sarepta, pp. 74-119. [in Russian]

[2] S.O. Terekhin, German Settlements in Russia. An Architectural Phenomenon, Saratov: Kadr, 1999, 216 p. [in Russian]

[3] V.V. Serebryanaya, The Religious Architecture of Volgogradskaya Oblast, Volgograd, 2002, pp. 145-149, 306310. [in Russian]

[4] Travel of Carmelite monks Along the Volga (1606-1607). Tsaritsyn in Travel Notes, Diaries, and Memoirs of Contemporaries (late 16th century - 1917), Volgograd, 2005, pp. 31-48. [In Russian]

[5] The State Archive of the Saratov Region. Fund 1. Op. 1. F. 2436. [in Russian]

[6] Russian State Historical Archive. Fund 821. Op. 125. F. 2513; Fund. 821. Op. 131. F. 209. [in Russian] 